\title{
PROBLEMS IN RESIDENTIAL TENANCY LAW REVEALED BY HOLLER $V$ OSAKI
}

\author{
Mark Bennett*
}

This article argues that the recent series of judgments in the Holler v Osaki litigation reveals concerning features of our residential tenancy law contained in the Residential Tenancies Act 1986 and its application by the Tenancy Tribunal and the courts. The law relating to residential tenancies is important: it regulates both tenants' ability to access the basic need of shelter and to satisfy their desire for home, and the financial investments of landlords. It is meant to allow landlords and tenants to understand their rights and obligations so that they may apply the law to their situations without legal assistance. However, Holler v Osaki illustrates the vagueness and therefore uncertainty concerning key legal rules within the Act, which led to the pre-existing understanding of the law being upended and the paralysis of the Tenancy Tribunal's ability to deal with careless damage. This article also highlights inconsistencies in the decisions of Tenancy Tribunal adjudicators, who applied completely different interpretations of the law to substantially identical facts.

\section{INTRODUCTION}

In 2009, Mrs Osaki allowed a pot of oil to boil over while cooking, having been distracted by her children. This caused a fire that damaged her home - a house that her husband, Mr Osaki, rented from Holler and Rouse. The damage was repaired at a cost of over $\$ 216,000$ - which was met by the appellant's insurer, AMI Insurance (AMI). AMI exercised its right to bring a subrogated recovery action against the Osakis in the names of Holler and Rouse, ${ }^{1}$ claiming the cost of repair. ${ }^{2}$ But what might seem a straightforward case of the Osakis' liability for negligent damage turned out to be a case that culminated in a decision of the Court of Appeal upturning the pre-existing understanding of the

* Senior Lecturer, Faculty of Law, Victoria University of Wellington. I thank the anonymous reviewers, Bill Atkin, Thomas Gibbons, Bridgette Toy-Cronin and my colleagues at Victoria University who attended a staff seminar on this topic for their comments. I also thank the editors for their comments and corrections.

1 See generally Sheehan v Watson [2010] NZCA 454, [2011] 1 NZLR 314; and Paul Michalik and Christopher Boys Insurance Claims in New Zealand (LexisNexis, Wellington, 2015) at ch 12.

2 Hollerv Osaki [2014] NZHC 1977, [2014] 3 NZLR 791 [Holler v Osaki (HC)] at [2]. 
law, thereby removing the Tenancy Tribunal's ability to hold tenants liable for their negligent damage to their landlord's property in many cases. ${ }^{3}$

Although it seldom reaches such heights of our appellate hierarchy, residential tenancy law is important. It regulates both the tenant's ability to access the basic need of shelter and to satisfy their desire for home, and the landlord's control over their financial investments. In many cases, more access for the tenant means less control for the landlord, so some "balance" needs to be struck. As in many jurisdictions, in New Zealand this balance is set out in statutory residential tenancy law, with the Residential Tenancies Act 1986 (RTA) containing most of the law of residential tenancies. The recent series of judgments in the case of Holler $v$ Osaki reveals some concerning features of our residential tenancy law that have caused problems in its application by the Tenancy Tribunal and the courts. As David Grinlinton observes, it has "altered the delicate balance in the landlord/tenant relationship and specifically the ability of landlords to enforce basic obligations of tenants to take care of premises". ${ }^{4}$ This article examines how the Holler v Osaki decisions caused this change, but it does not discuss the policy issues relating to exoneration and the practical problems that the decision has caused - which have been comprehensively analysed by Grinlinton in two recent articles, ${ }^{5}$ and which were discussed at the time of the decisions by other commentators. ${ }^{6}$ Instead, it focuses on two other notable features of the litigation that reveal problems in our residential tenancy law.

First, it identifies the interaction of the RTA with the Property Law Act 2007 (PLA) through s 142 of the RTA as another example of the lack of clarity in our law of residential tenancies ${ }^{7}-$ one

3 Holler v Osaki [2016] NZCA 130, [2016] 2 NZLR 811 [Holler v Osaki (CA)].

4 David Grinlinton "The boundaries between residential tenancies and commercial leases" [2017] NZLJ 4 at 7.

5 Grinlinton, above n 4; and David Grinlinton "Tenant Liability for Negligent Damage Following Holler v Osaki" (2017) 27 NZULR 626.

6 See Adam de Hamel "A prophetic case - the liability of tenants under the Residential Tenancies Act 1986" [2016] NZLJ 250; Thomas Gibbons "Holler v Osaki" (2016) 17 BCB 307; Thomas Gibbons "Holler v Osaki" (2015) 16 BCB 132; and Thomas Gibbons "Case Note: Holler v Osaki" (2014) 22 Wai L Rev 183. The practical problems are also set out in a letter from Melissa Poole (Principal Tenancy Adjudicator) to Nick Smith (Minister of Building and Housing) regarding Holler v Osaki (CA), above n 3, (23 September 2016). See also Po Tsai "Holler v Osaki: The Careless Tenant Exonerated" (LLB (Hons) research paper, Victoria University of Wellington, 2017).

7 See also the lack of clarity that surrounds the requirement that houses subject to a residential tenancy must be free from dampness: see Sarah Bierre, Mark Bennett and Philippa Howden-Chapman "Decent Expectations? The Use and Interpretation of Housing Standards in Tenancy Tribunals in New Zealand" (2014) 26 NZULR 153. Other interpretive problems include the role of the s 85 discretion in the RTA to decide cases according to their merits and justice discussed in Part IV(C), and the question of illegal tenancies under ss 2 and 137 of the RTA, as interpreted by Anderson v FM Custodians [2014] NZHC 382 and then applied (or distinguished) in the Tenancy Tribunal in orders such as Tan v Arzi TT Manukau 4024444, 7 November 2016; Pihama $v$ Yinwen TT Lower Hutt 4045048, 14 December 2016; Smith v Arzi TT Manukau 4049853, 31 July 2017; and Sneddon v Paddi \& Co Ltd TT Palmerston North 4104107, 16 November 2017. 
which the courts found difficult to understand, and which the courts in Holler v Osaki interpreted as having a meaning completely contrary to the prior understanding of the law. The new interpretation upends settled Tribunal practice, for in the many years since the relevant provision was enacted tenants have been ordered to pay compensation for damage for their careless acts. According to new interpretation, from 2007 tenants should have been exonerated from liability for careless damage where their landlord was insured.

Second, and perhaps of more concern, when the new interpretation of the law was stated by the District and High Courts, it was not always applied to residential tenancy disputes where it was relevant. The Tenancy Tribunal did not uniformly apply the exoneration provisions until two years later, when the Court of Appeal confirmed the lower courts' interpretation. This is demonstrated by examining over 100 Tribunal orders from the date of the District Court decision onwards. This deep analysis of Tribunal practice has been enabled by the relatively recent keyword search functionality on the Ministry of Justice's database of Tribunal orders, and it provides important insights into the way that Tribunal adjudicators addressed the fundamental change to tenant liability caused by Holler vOsaki.

This article has four main parts. Part II sets out the key legal question in Holler v Osaki, and then Part III analyses how the Tribunal and courts interpreted the law. The article then examines the problems identified above: Part IV criticises the vague provisions in our law of residential tenancies, and then Part V discusses the problems in the Tenancy Tribunal's application of the law.

\section{THE EXONERATION OF TENANTS' LIABILITY FOR DAMAGE}

\section{A The Basic Legal Question}

The one important legal question in Holler $v$ Osaki is a difficult issue of statutory interpretation concerning the relationship between the RTA and provisions of the PLA that exonerate tenants from their liability for damage to the property they are renting. Section 268 of the PLA identifies the circumstances where the provisions apply, namely where leased premises are destroyed or damaged by "fire, flood, explosion, lightning, storm, earthquake, or volcanic activity" or by "the occurrence of any other peril against the risk of which the lessor is insured". In these circumstances s 269 of the PLA applies to exonerate the tenant from liability - even if the lessee's negligence caused or contributed to the event that caused the damage. Section 269 provides that the lessor must not require the lessee to meet the cost of "making good" the damage, or indemnify the lessor for doing so, or pay damages to remedy the loss. Indeed, if the lessee is contractually obliged to make good the loss, the lessor must indemnify the lessee. ${ }^{8}$ However, s 269(3) limits this exoneration of the lessee to situations where they have not damaged the property intentionally, or by an act or omission in the premises that

8 Property Law Act 2007, s 269(2). 
constitutes an imprisonable offence, or if their act or omission has made insurance moneys irrecoverable.

If these exoneration provisions apply to residential tenancies, they would exonerate the Osakis' liability, because the damage was caused by a fire and the exceptions in s 269 do not apply. ${ }^{9}$ But the difficult question is whether the exoneration provisions apply to residential tenancies at all. Although under s 8(1) the PLA applies to land and other property in New Zealand, s 8(4) provides that, if any of its provisions are inconsistent with the provisions of another enactment, the other enactment prevails. Although the RTA does not contain any reference to the exoneration of liability, it does make tenants liable for damage they cause to the property, ${ }^{10}$ for which the Tribunal may award compensation. ${ }^{11}$ Furthermore, s 142 of the RTA "regulates" the application of the PLA to tenancies to which the RTA applies:

\section{Effect of Property Law Act 2007}

(1) Nothing in Part 4 of the Property Law Act 2007 applies to a tenancy to which this Act applies.

(2) However, the Tribunal, in exercising its jurisdiction in accordance with section 85 of this Act, may look to Part 4 of the Property Law Act 2007 as a source of the general principles of law relating to a matter provided for in that Part (which relates to leases of land).

This provision has been described as "awkwardly expressed"12 and as "paradoxical, if not starkly contradictory". ${ }^{13}$ It is not obvious how the s $142(1)$ direction that nothing in pt 4 of the PLA applies to residential tenancies (the "exclusion provision") is consistent with the s 142(2) discretion that the Tribunal "may look to" that Part as a source of general principles of leases (the "general principles discretion").

Against this statutory background, the basic line of argument of each side is obvious: the lessors will say that the exoneration provisions (ss 268 and 269 of the PLA) do not apply to residential tenancies because of the exclusion provision (s 142(1) of the RTA), whereas the lessees will argue that those provisions contain general principles of the law of leases that are applicable under the general principle discretion (s 142(2) of the RTA). Everything should therefore turn on how the concept of the PLA being looked to as a "source of general principles" is understood.

9 It was held in the District Court and High Court that Mrs Osaki would also be protected from liability despite not being the lessee or agent of the lessee: Holler v Osaki (HC), above n 2, at [51].

10 Residential Tenancies Act 1986, s 40(2)(a).

11 Sections 77(2)(n) and 78(1)(d).

12 Holler v Osaki (HC), above n 2, at [29].

13 Osaki v Holler TT Auckland 12/02284/AK, 23 October 2012 [Osaki v Holler (TT)] at [51]. 


\section{B Why does this Legal Question Exist?}

This legal question exists due to the complicated legislative and policy history of the provisions. ${ }^{14}$ There are two aspects to this point: the reason that the exoneration provisions apply only to commercial leases, and the reasons for creating the general principles discretion in s 142(2). The latter will be addressed in the following part.

The reason that the PLA provisions exonerating commercial tenants from liability for careless damage exist at all is that Parliament accepted the suggestion of the Law Commission in its work, conducted in the first half of the 1990s, on proposals for a new Property Law Act. ${ }^{15}$ The Law Commission considered that, where a property is damaged by the negligence of a lessee or their licensee and that property is insured by the lessor, the lessee should be immune from liability. ${ }^{16}$ As summarised by Keane $\mathrm{J}$ in the High Court, the policy reasoning was that: ${ }^{17}$

\footnotetext{
... the lessor could be anticipated to have insured the property, and to have imposed on the lessee all or most of the cost, either specifically or as an element of the rent. Yet in many cases, the lessee was uninsured and often assumed that the lessor's insurance would protect them.
}

The Law Commission's report therefore proposed that the lessee should be exonerated from liability by default. ${ }^{18}$

Yet when the PLA was enacted in 2007, the exoneration provisions were not expressly made applicable to residential tenancies, and the exclusion provision of the RTA seemed to exclude their operation. ${ }^{19}$ The Tenancy Tribunal continued to award compensation for careless damage by tenants, in the belief that the exoneration provisions did not apply to residential tenancies. ${ }^{20}$

Indeed, because it was thought that the exoneration provisions did not apply to residential tenancies, there was pressure to alter this position. Tenants' liability for their negligent actions had earlier been dramatically illustrated by a 2002 District Court decision in which a landlord's insurer

14 Grinlinton, above n 5, at 628-634. See also Tsai, above n 6, at 19-26.

15 Grinlinton, above n 5, at 632-633.

16 Law Commission A New Property Law Act (NZLC R29, 1994). See also Holler v Osaki (HC), above n 2, at [14]-[15].

17 At [14].

18 At [15].

19 Grinlinton, above n 5, at 634-635.

20 See David Grinlinton Residential Tenancies: The Law and Practice (4th ed, LexisNexis, Wellington, 2012) at $144-145$. 
was awarded $\$ 80,000$ against the tenants. ${ }^{21}$ The Judge made strident obiter comments on the injustice of the result, echoing the Law Commission's perspective: ${ }^{22}$

The outcome of this proceeding, though in accordance with the law, is unjust. It is unlikely that the defendants were ever aware that their landlord (or the landlord's insurer acting by right of subrogation) might sue them for major damage to their flat, even if caused by the carelessness of one of them. I have no doubt that, while most residential tenants assume (almost invariably correctly) that their landlords insure and will be indemnified against damage to, or the destruction of, the insured property, they have little or no understanding of the insurer's right of subrogation. They assume that if a landlord is insured, they, the tenants, are not at risk. Few tenants insure against their potential liability to their landlord. Some do so incidentally to insuring their own possessions. The consequence is that, in the event of serious loss or damage to the leased property, the tenants (including flatmates not at fault) find themselves unexpectedly liable to the insurer, acting in the name of the landlord, for losses that may bankrupt them. ... the entry of judgment against tenants is usually unjust because insurance premiums are factored into landlords' costs when fixing rents and they are effectively paid by the tenants. I note also that insurers accept the risk of leased residential properties knowing that the tenants are unlikely to have liability insurance or other means to pay claims and that the recovery of substantial contribution to the insured loss from tenants must be relatively uncommon.

Due to this and other cases, there were further legislative proposals to extend the immunity to residential tenants in $2008,{ }^{23}$ but these failed and such provisions were not included in the major amendments to the RTA passed in $2010 .^{24}$

\section{THE HOLLER V OSAKI DECISIONS}

This short survey of the development of the law explains the surprise that was felt by residential landlords when the courts held in Holler $v$ Osaki that in fact the exoneration provisions do apply to residential tenancies. The following part only briefly describes the reasoning in the key decisions, because they have been discussed exhaustively elsewhere. ${ }^{25}$

\section{A Tenancy Tribunal}

When the case reached the Tenancy Tribunal (after a High Court decision had established the Tribunal's jurisdiction), ${ }^{26}$ it held that the exoneration provisions were not applicable to residential

21 Harrison v Shields DC Dunedin NP435/00, 25 September 2002.

22 At [42]-[43].

23 Residential Tenancies Amendment Bill (No 2) 2008 (258-1), cl 26

24 Residential Tenancies Amendment Act 2010.

25 In particular see Grinlinton, above n 4; Grinlinton, above n 5; and Tsai, above n 6.

26 Holler v Osaki [2012] NZHC 939 [Holler v Osaki (summary judgment)]. 
tenancies, essentially because the exoneration provisions had not been expressly made applicable to residential tenancies by Parliament and because they would be inconsistent with the RTA's damage provisions. ${ }^{27}$ Arguments based on the justice of the case could not be used where the substance of the law relating to liability for damage was against the defendant, ${ }^{28}$ and the s $142(2)$ argument that the exoneration provisions contained general principles of the law of leases could not be sustained in light of the RTA's clear statements of tenant liability for damage in ss $40-41 .^{29}$

\section{B District Court}

In contrast, in the District Court Judge Mathers held that the exoneration provisions do apply to residential tenancies. The basic reason was that because s 85(2) of the RTA directed the Tenancy Tribunal to resolve disputes according to the general principles of the law relating to the matter and the substantial merits and justice of the case, and that "it would be very unfair if a well-resourced commercial tenant and its employees were exonerated, but a residential tenant not". ${ }^{30}$ The Judge applied the exoneration provisions as the legal rules that allowed justice to be done between the parties. $^{31}$

\section{High Court}

When the question of exoneration reached the High Court, Justice Keane identified a key interpretive question as the relationship between the two subsections of s 142 -the exclusion provision and the general principles discretion. ${ }^{32}$ The Judge identified four attributes of the RTA which s 142 had to be understood in relation to: its purpose of setting out tenant and landlord rights and allowing disputes to be resolved efficiently; its applicability only to residential tenancies and not similar living arrangements that are expressly excluded ${ }^{33}$ ("the rights and duties of analogously placed tenants, and their liabilities and immunities, ought not to differ radically or inexplicably"); ${ }^{34}$ and the direction in $\mathrm{s}$ 85 to decide according to the substantial merits of a dispute. ${ }^{35}$

27 Osaki v Holler (TT), above n 13, at [80]-[87].

28 At [65] and [81].

29 At [64] and [81].

30 Osaki v Holler DC Auckland CIV-2012-004-002306, 23 September 2013 [Osaki v Holler (DC)] at [49] and [55]-[58].

31 At [56]-[57].

32 Holler v Osaki (HC), above n 2, at [30].

33 See Residential Tenancies Act, s 5.

34 Holler v Osaki (HC), above n 2, at [37].

35 At [36]-[40]. 
But seemingly the most important of the four attributes Keane $\mathbf{J}$ identified was his categorisation of the ways in which the RTA refers to other legislation. He identified s 142 as a provision that identifies the jurisdiction of the Tribunal, ${ }^{36}$ rather than as a restriction on the statutory matrix that the Tribunal or other courts must apply to residential tenancies. The purpose of s 142(2) of the RTA in both the original and amended versions was to make it clear that, despite the RTA's attempt to clarify and bring together residential tenancies law, the Tribunal is still required to take into account general principles of law relevant to leases. ${ }^{37}$

This meant that the exoneration provisions could be applied to residential tenancies, which Keane $\mathrm{J}$ also thought accorded with matters of principle: ${ }^{38}$

... in principle there is no essential difference between the forms of tenure that these two statutes govern. Both forms of tenure are, to varying degrees, governed by the same general principles of law. The liability risk that lessees face under that form of tenure, and that faced by tenants under that cognate form of tenure, is essentially indistinguishable. If one is to be immune from suit, so too in logic and equity, and to the same extent, should the other.

\section{Court of Appeal}

The Court of Appeal agreed with Keane J's conclusion, but for different reasons. It observed that although ss 85(2) and 142(2) require the Tribunal to apply general principles of the law of leases in resolving disputes, ${ }^{39}$ there is a tension between this and $\mathrm{s}$ 141(1), which excludes the application of the PLA. ${ }^{40}$ But given that s 142(2) requires Tribunal adjudicators to apply "general principles" of the law of leases, ${ }^{41}$ the exoneration provisions were actually "very good, if not the best candidates" for being the general principles identified in $\mathrm{s} 142(2) .{ }^{42}$

The Court of Appeal also examined legislative history, particularly the Law Commission's work on a new Property Law Act, which clearly supported the exoneration provisions' application to residential tenants. ${ }^{43}$ The Court also identified evidence from Hansard that indicated that the Law Commission's recommendations were being given effect to by Parliament. ${ }^{44}$ However, the fact that

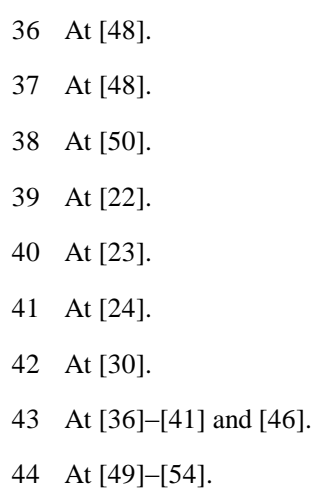


Parliament generally intended to give effect to the Law Commission's recommendations cannot show that this intention existed for each particular recommendation if the relevant statutory language suggests otherwise. Further, Grinlinton reads the parliamentary evidence as showing that "the measures were intended to apply to commercial leases only". 45

Despite these and other objections to such an interpretation, ${ }^{46}$ ultimately the Court of Appeal concluded that the exoneration provisions applied to residential tenancies. ${ }^{47}$ Although the Court had noted the question of whether the Tribunal has a discretion to apply the exoneration provisions, or whether it must do so in relevant cases, ${ }^{48}$ in its conclusion and decision it is ambiguous: it speaks both of the Tribunal being "entitled" to apply the provisions and that it "may" do so, but also of tenants being (seemingly automatically) immune from a claim where the exoneration provisions apply. ${ }^{49}$

Ultimately, whether or not one finds the interpretive reasons offered by the courts for the PLA exoneration provisions to apply to RTA tenancies, the reasoning provided is complex and can hardly be seen as something that tenants and landlords could have understood as determining their rights and obligations. This is the first major problem revealed by Holler $v$ Osaki: the lack of clarity in parts of the RTA.

\section{THE PROBLEM OF THE LACK OF CLARITY IN THE RTA}

\section{A The Goal of Clarity for Self-Application}

This part identifies important areas of imprecision in the RTA. This lack of clarity is contrary to one of the stated goals of the RTA: to simplify the law relating to residential tenancies, in part by bringing together the main rules in one Act. ${ }^{50}$ It is a partial codification of the rights and obligations of tenants and landlords; as the Minister of Housing, Phil Goff, stated at the time it was enacted, the legislation "clearly defines the rights and responsibilities both of landlords and of tenants", and constituted an attempt to bring "all law relating to landlords and tenants into one statute". ${ }^{51}$ Any waiver of tenant rights or powers being of no effect. ${ }^{52}$

45 Grinlinton, above n 4, at 6 citing (14 November 2006) 635 NZPD 6461 and the introductory notes to the Property Law Reform Bill 2006 (89-1) at 79. See generally Grinlinton, above n 5, at 643-644; and Tsai, above n 6, at 22-26.

46 See Grinlinton, above n 5, at 639-644.

47 At [57]-[58].

48 At [32].

49 At [57]-[58].

50 Residential Tenancies Act, long title; and Grinlinton, above n 20, at 3-5.

51 (19 September 1985) 466 NZPD 6896-6897.

52 Residential Tenancies Act, s 11(3). 
This codification was a welcome development, as it helps landlords and tenants to know the rules that govern their relationship. In a lecture examining "Statutes and the Ordinary Person", Professor John Burrows observed: "It would be good if ordinary members of the community could consult the law that affects them, and understand it". ${ }^{53}$ This is especially so where statutes involve rights and duties that people will "self-apply" to their own actions; in such cases, the law should be comprehensible to anyone.$^{54}$ One of Professor Burrows' examples was the RTA, ${ }^{55}$ and it is indeed a very good example: ${ }^{56}$

... rental housing regulation applies to most people at some time during the course of their lives and some people may never live outside of its scope. Access to shelter and a home is one of the most important of our interests, and the payment for this is one of our greatest economic expenses. ... Self-application is also likely: it seems safe to assume that most tenants - and probably also many landlords - do not seek professional legal advice before signing tenancy agreements. Furthermore, the involvement of lawyers or advocates in the Tenancy Tribunal is generally prohibited (subject to specified exceptions), which, combined with the low value of such disputes, means that lawyers are generally not involved and that consequently there are few experts in this law. Yet people usually do know that there is an important legal relationship between landlord and tenant, and that in cases of dispute the exact nature of their rights and obligations is important. Thus, if there is a statute that should be clear enough for most ordinary people to understand, it is the Residential Tenancies Act 1986 ...

In addition, the aspiration for layperson application of the law is reflected in the fact that the adjudicators tasked with applying the law are not required to be legally qualified, ${ }^{57}$ though they usually are. The point is that residential tenancy law is particularly for laypersons, and therefore should be as clear, coherent and "codified" (brought together in one place) as possible.

The RTA achieves this goal only partially. The Act does bring together most of the rights and obligations of landlords and tenants in one place and in relatively comprehensible language. There are exceptions to this, for example the provisions that regulate the minimum standards of housing quality and condition found in $\mathrm{s} 45,{ }^{58}$ although the latest developments in this area (insulation and smoke alarms) are admirably clear. ${ }^{59}$ However, major problems remain in the RTA's clarity.

53 John Burrows "Statutes and the Ordinary Person" (2003) 11 Wai L Rev 1 at 1.

54 At $1-5$.

55 At 2 .

56 Bierre, Bennett and Howden-Chapman, above n 7, at 153-154 (footnotes omitted).

57 Residential Tenancies Act, s 67(5)(b).

58 See generally Bierre, Bennett and Howden-Chapman, above $\mathrm{n} 7$.

59 Residential Tenancies Amendment Act 2016, ss 43-44, inserting ss 138A-138B into the Residential Tenancies Act. 


\title{
$B$ The Interaction with the PLA under s 142
}

As has been shown above, s 142 is not clear in identifying how the RTA's rules relate to the law of leases contained in the PLA. The exclusion provision, s 142(1) reflects the RTA's status as a special "codified" regime for residential tenancies by stating that the PLA's rules concerning the law of leases do not apply.

Prior to 2007, this would have been the end of the legal argument: the PLA does not apply. However, s 142(2) of the RTA was amended in 2007 at the time the new PLA was enacted, creating the general principles discretion. It is not clear how this can be applied coherently with s 142(1). As stated in the Tenancy Tribunal order in Osaki v Holler: "Section 142 presents at first blush as paradoxical, if not starkly contradictory, in the direction it provides to the tribunal."60

To give a meaning and application to s 142(2), it is necessary to identify the general principles that might be sourced from pt 4 of the PLA. However, the Court of Appeal observed, "none of the provisions in that part can easily be categorised" as general principles. ${ }^{61}$ This was part of its reason for saying that the exoneration provisions are the best candidates to be general principles - otherwise s 142(2) would serve no purpose.

However, Grinlinton has provided clear examples of pt 4 rules that are better examples of "general principles", including the implied covenants of quiet enjoyment and non-derogation from grant, rules relating to the lessor not giving consent to lessee dealings with the lease and rules relating to nonrenewal and cancellation of leases. ${ }^{62}$ Many of these provisions, Grinlinton notes, "repeat, and often embellish, long-standing 'general principles' of the common law". ${ }^{63}$ Some of these will have little application in the residential tenancy context: ${ }^{64}$ for example, cancellation of lease rules in the PLA ${ }^{65}$ will generally be supplanted by the rules relating to termination of tenancies in the RTA, ${ }^{66}$ and there will be no mortgagee or receiver of a residential tenancy. ${ }^{67}$ Nevertheless, the point is that there are many provisions in pt 4 that could be applied as general principles of the law of leases, so that the exoneration provisions need not be forced into that category because there are no other options.

\author{
60 At [51]. \\ 61 At [24]. \\ 62 Grinlinton, above n 4, at 6; and Grinlinton, above n 5, at 642 . \\ 63 Grinlinton, above $\mathrm{n} 5$, at 642. \\ 64 At $642-643$. \\ 65 Property Law Act, ss 243-264. \\ 66 Residential Tenancies Act, ss 50-66. \\ 67 Property Law Act, s 254.
}


Further possibilities are found in the Tenancy Tribunal's own use of s 142(2). In McAllister v Saha, the Tribunal used judicial discussions of the meaning of "unreasonably withheld" consent in the context of s 226(2) of the PLA for the interpretation of a similar provision of the RTA $-\mathrm{s} 44 .{ }^{68} \mathrm{In}$ Virginian Properties Ltd $v$ James, the adjudicator provided a thorough analysis of s 142(2) and identified general principles of the law of leases in both pt 4 of the PLA and in the common law relating to whether a former landlord can sue their former tenant after the former landlord had transferred the reversion - although the adjudicator preferred to apply the common law principles rather than the PLA. ${ }^{69}$

Virginian Properties suggests another way of identifying general principles in pt 4, namely if the particular statutory rule was a codification of the common law principles of leases pertaining to a matter. Then the Tribunal could legitimately say that the rule reflected or confirmed the general principles of the law of leases that should be applied to a matter. In contrast, if the rule altered the preexisting common law rule, this cannot be seen as a general principle of the law of leases pertaining to that matter, as the PLA rule alters those general principles of law. A similar argument on this point is made by Grinlinton, who observes that the exoneration provisions: ${ }^{70}$

\footnotetext{
... introduce quite specific reforms to the well-established "general principles of law" that had previously applied to tenant liability for damage. It is therefore arguable that ... those reforms are in fact the "worst candidates" due to their very specific remedial purpose coupled with the clear legislative intention that pt

4 was not directed at residential tenancies, but rather to reform the law relating to commercial leases.
}

If the reply to this is that the new rule itself is a general principle of law, a plausible response would be that: (a) this approach is contrary to s 142(2)'s language of "source of the general principles" because this would mean there would be no distinction between the provisions of pt 4 and the "general principles"; 71 and (b) this approach nullifies s 142(1) by allowing a court to simply apply the provisions of pt 4 .

Whatever one's view on the correct interpretation and result, it is clear that s 142(2) presents difficulties of interpretation to the legally-trained, and is incomprehensible to the layperson. From both perspectives, the replacement of the original s 142(2) of the RTA by the PLA was ill-conceived. The old RTA s 142(1) excluded the operation of the Property Law Act 1952 (PLA 1952) rules concerning leases from applying to residential tenancies in the same terms as the current law does, but the old s 142(2) was a "savings" provision stating that those PLA 1952 provisions would continue

68 McAllister v Saha TT Tauranga 14/00385/TG, 17 June 2014. See also Thompson v Te Aro Tenancies Ltd TT Wellington 14/01671/WN, 10 March 2015.

69 Virginian Properties Ltd v James TT Porirua 4005816, 4 March 2016. See also McIntosh v Sutcliffe TT Wellington 4035646, 7 September 2016.

70 Grinlinton, above n 5, at 643. See also Grinlinton, above n 4, at 6.

71 A point also made in Virginian Properties, above n 69, at [21]. 
to apply to fixed-term or service tenancies that they had applied to immediately before the commencement of the RTA, but "subject to the provisions" of the RTA. ${ }^{72}$ Thus, the new and old versions of s 142(2) have completely different effects: the new provision gives us the uncertain concept of general principles of the law of leases contained in the PLA being part of the Tribunal's decision-making resources for all residential leases. The reasoning for this fundamental change provided in the Law Commission's report, as recounted by the Court of Appeal, does not shed any light on why the change was desired or the mischief it responded to. ${ }^{73}$ Section 142 is therefore just as unclear in its purpose as it is in its textual meaning.

Although Grinlinton criticises the Holler v Osaki decisions as having "created confusion and uncertainty in the relatively settled law applicable to residential tenancies", ${ }^{74}$ it seems that this confusion and uncertainty was inherent in the law contained in s 142.

One solution is on the horizon. The problem would be removed by the Residential Tenancies Amendment Bill (No 2), which would repeal s 142(2). ${ }^{75}$ This would allow the Tribunal to continue to apply general legal principles of the law of leases that are not inconsistent with the RTA under s 85 . However the mention of the latter section leads to another problem in the clarity of our residential tenancy law.

\section{The Tribunal's Adjudicative Role under s 85}

Unfortunately, s 142 is not the only confusing provision in the RTA. Section 85(2) states:

The Tribunal shall determine each dispute according to the general principles of the law relating to the matter and the substantial merits and justice of the case, but shall not be bound to give effect to strict legal rights or obligations or to legal forms or technicalities.

To apply this section, the Tribunal must identify "general principles of law" and the "substantial merits and justice" of the case, as distinct from "strict legal rights" and "legal forms or technicalities". Such an imprecise direction is unwelcome in a statute that is supposed to clarify the rights and obligations of landlord and tenant so that they can know them and apply them to their interactions, and which is full of precise definitions, special exclusions of its operation, and a myriad of procedural formalities. It should be replaced with a section that provides with more precision what adjudicative discretion is required or allowed.

For example, it may be that the provision should simply make clear that strict forms and technicalities need not be followed where this would be contrary to the justice of the case, which is a

72 See Holler v Osaki (CA), above n 3, at [42].

73 At [44]-[45].

74 Grinlinton, above $\mathrm{n} 4$, at 7.

75 Residential Tenancies Amendment Bill (No 2) 2017 (258-1), cl 21. 
kind of codification of a philosophical concept of equity. ${ }^{76}$ This was the interpretation given by the High Court in Ziki Investments (Properties) Ltd v McDonald, where the Judge stated that s 85 "simply means that technical requirements, such as matters of form or time, may not be strictly applied". ${ }^{77}$ In Welsh v Housing New Zealand Ltd $^{78}$ it was held that a decision based on the substantial merits must be in terms of the general rules and principles of the law, rather than being based on underlying moral principles unconnected to the law. ${ }^{79}$ Whether this extends beyond not strictly applying technical requirements of time or form is not clear, but this statement of the correct approach was affirmed by the District Court and High Court in Holler v Osaki. ${ }^{80}$

However, s 85 has also been used in circumstances other than to avoid technicalities of form or time limit. For example, it has been used to "pierce the corporate veil" where the landlord companies that were liable to the tenant had been wound up. ${ }^{81}$ It was applied in Holler $v$ Osaki to extend the exoneration provisions to the wife of the tenant, when the statute only referred to the tenant. ${ }^{82}$ As will be discussed below, some adjudicators used s 85 to avoid the consequences of Holler $v$ Osaki by making the tenants liable for damage in respect of which they should have, strictly legally speaking, been exonerated from any liability.

These might be regarded as good uses of s 85 from a normative perspective, as they allow the Tribunal to achieve results that arguably align with the underlying reasons for the rules we have, and to achieve justice on the merits of the case. But these uses go beyond the court not strictly applying technicalities of form and time, as they involve disregarding the technical position relating to the persons who are bound by obligations. Where adjudicators disagree on the role of s 85 , they will be exercising their discretion in different ways, leading to inconsistency in adjudicative approach.

Whatever the "best" meaning and purpose of s 85 is, the courts or Parliament should act quickly to make clear the meaning and purpose that should be applied. In addition, the question as to whether it is legitimate for courts to exercise the same powers under s 85 - when that section only refers to the Tribunal having those powers - is another one that should be definitively set out in the RTA. ${ }^{83}$

76 Roger Shiner "Aristotle's Theory of Equity" (1994) 27 Loy L Rev 1245.

77 Ziki Investment (Properties) Ltd v McDonald [2008] 3 NZLR 417 (HC) at [69]. See also Virginian Properties, above n 69.

78 Welsh v Housing New Zealand Ltd HC Wellington AP35/2000, 9 March 2001.

79 See also Molijn v Tanner Group Ltd TT Thames 4021465, 14 June 2016.

80 Osaki v Holler (DC), above n 30, at [47]-[48] and [51]; and Holler v Osaki (HC), above n 2, at [39]-[40].

81 Cross $v$ Walker TT North Shore 4012824, 2 September 2016 at [2]-[4].

82 Osaki v Holler (DC), above n 30, at [52]-[53].

83 See Grinlinton, above n 4, at 6. 


\section{THE PROBLEM OF UNEVEN EFFECT IN THE TENANCY TRIBUNAL}

The uncertainties identified above in the RTA's normative framework are enough to warrant legislative action to clarify the law. Yet further evidence of the problematic nature of aspects of our residential tenancy law and its application is revealed by the way that the Tenancy Tribunal responded to the decisions of the courts. The Tribunal is the main forum for the resolution of residential tenancy disputes, having original jurisdiction over most such matters,${ }^{84}$ and with appeals only being available where the dispute has a value over $\$ 1,000 .{ }^{85}$ Tribunals sit around the country in most places that have a District Court, and are staffed by around 40 adjudicators, overseen by a Principal Tenancy Adjudicator. ${ }^{86}$ The Ministry of Justice's online database of Tenancy Tribunal orders holds orders made in the previous three years. This study conducted a wide-ranging search to examine how the Tribunal dealt with the upturning of the law of tenant liability in the Holler v Osaki decisions.

This study found a problem in the consistency of Tribunal practice. For almost three years after the District Court decision, the Tribunal's application of the exoneration provisions was inconsistent, with some Tribunals applying the Holler v Osaki decisions as binding precedent, and some not applying it at all or distinguishing it. This resulted in different law on liability for careless damage being applied in different Tribunals.

To summarise, initially, the Tribunal seems not to have applied the District Court's ruling that the exoneration provisions covered residential tenancies, when it appears to have been bound by the doctrine of precedent to do so. After the High Court decision, there was a split between Tribunal orders that applied the exoneration provisions to all careless damage claims and those that did not apply it to any such claims. Then, after the Principal Tenancy Adjudicator issued a Practice Direction interpreting the High Court decision limiting the scope of the exoneration provisions for residential tenancies, ${ }^{87}$ most Tribunal orders either did not refer to Holler $v$ Osaki at all or made a distinction between catastrophic events where the exoneration provisions did apply, and other damage to which they did not apply; however other Tribunals applied the exoneration provisions in full. It was only after the Court of Appeal's decision that uniformity was achieved and the exoneration provisions were applied in full to residential tenancies by the Tribunal. For reference, a table summarising the timeline of the events discussed in this part is as follows:

84 Residential Tenancies Act, s 77.

85 Section 117

86 Ministry of Justice "Tenancy Adjudicators" (7 July 2017) <www.justice.govt.nz>.

87 Principal Tenancy Adjudicator Practice Direction 1/2014 (2014). 


\begin{tabular}{|c|c|c|}
\hline Date & Event & Effect in Tenancy Tribunal \\
\hline 23 September 2013 & $\begin{array}{l}\text { District Court decision } \\
\text { (applies exoneration } \\
\text { provisions }(\mathrm{EP}))\end{array}$ & $\begin{array}{c}\text { No } 2013 \text { orders available online; no } \\
\text { effect before High Court (HC) } \\
\text { decision }\end{array}$ \\
\hline 20 August 2014 & HC decision (applies EP) & $\begin{array}{l}\text { Many orders follow HC by applying } \\
\text { EP completely; a similar number do } \\
\text { not refer to HC or apply EP; a small } \\
\text { number distinguish HC }\end{array}$ \\
\hline 12 December 2014 & $\begin{array}{c}\text { Principal Tenancy } \\
\text { Adjudicator's } 2014 \text { Practice } \\
\text { Direction (PD) }\end{array}$ & $\begin{array}{c}\text { Most orders apply as PD interprets the } \\
\text { HC decision; some orders apply EP } \\
\text { completely }\end{array}$ \\
\hline 15 April 2016 & $\begin{array}{l}\text { Court of Appeal's (CA) } \\
\text { decision }\end{array}$ & $\begin{array}{l}\text { Orders apply CA decision and apply } \\
\text { EP completely }\end{array}$ \\
\hline 26 July 2016 & $\begin{array}{l}\text { Principal Tenancy } \\
\text { Adjudicator's } 2016 \text { Practice } \\
\text { Note }\end{array}$ & Application of CA decision continues \\
\hline
\end{tabular}

The uneven effect that is revealed by examining Tribunal practice is a problem from the perspectives of the doctrine of precedent and consistency. The District Court decision, and then the High Court decision, should have been understood as binding on the Tenancy Tribunal, even if it was under appeal. Questions of law decided on by the Tribunal may be appealed to the District Court, ${ }^{88}$ and then to the High Court ${ }^{89}$ and finally to the Court of Appeal. ${ }^{90}$ This is the precedential hierarchy on questions of law. Accordingly, the Tribunal treats higher court decisions on the law as binding. ${ }^{91}$ In one Tribunal order, the reasons for the decision stated: "The legal doctrine of stare decisis

88 Residential Tenancies Act, s 117.

89 Section 119.

90 Section 120.

91 See for example Ahuja v Maka TT Manukau 4015915, 13 January 2017; Wakefield v Hodgson TT Whangarei 4046156, 26 January 2017; Pihama v Yinwen, above n 7; Riddler v Beesley TT Masterton 4032041, 21 October 2016; Kereopa v Iskandar TT Manukau 4050265, 29 November 2016; Paul $v$ White TT 14/00096/NU, 17 March 2014; McDonald Real Estate Ltd v Graham TT New Plymouth 14/00368/NU, 8 August 2014; and Morrison v Portfolio Property Management Ltd TT Wellington 14/00194/WN, 15 April 2014. 
(decisions of courts higher in the judicial hierarchy bind lower courts/tribunals) means the Tribunal must follow District Court's decisions". ${ }^{92}$ Another order states: ${ }^{93}$

... I am bound, because of the legal principle of binding precedent (stare decisis - all tribunals exercising inferior jurisdiction are required to follow decisions of courts exercising superior jurisdiction), to apply

[the High Court decision] to the facts of the present matter.

In a case that turned on whether a High Court decision was binding on the interpretation of the meaning of "residential tenancies", the adjudicator conducted a thorough analysis of the concept of precedent, including this statement: ${ }^{94}$

The doctrine of precedent requires lower courts and tribunals to follow the judgments of courts above them in the same hierarchy, where the subject matter of the judgment is the same, or closely similar to, the subject matter of the case to be decided in the lower court or tribunal. Thus the Tenancy Tribunal is bound by the judgments of the District Court on appeal from the Tenancy Tribunal. Similarly, the District Court is bound by judgments of the High Court, the High Court by judgments of the Court of Appeal and the Court of Appeal by judgments of the Supreme Court of New Zealand.

Further, orders of the Tribunal later treated the High Court and Court of Appeal decisions in Holler v Osaki as binding. ${ }^{95}$ This part shows how this understanding of binding precedent was not effective in many Tribunal orders, and how this caused an inconsistency with those Tribunal orders that did follow precedent.

\section{A Effect of the District Court Decision}

Although Judge Mathers' decision in the District Court on 23 September 2013 ruled that the PLA exoneration provisions should apply to residential tenancies through s 142(2), this does not seem to have been applied by Tenancy Tribunals. As the online database does not extend back into 2013 - the orders remaining online for three years - there is no easily accessible evidence to show whether Judge Mathers' judgment had any effect during 2013. However, we can presume that the District Court decision had little effect and was not applied in the Tribunal, as the orders published in the database from January 2014 through to the High Court decision in August do not refer to it in the context of careless damage. ${ }^{96}$

92 Slade v Housing New Zealand TT Auckland 4054447, 23 December 2016 at [8].

93 Calquin v Cao TT Auckland 4046613, 19 December 2016 at [14].

94 Tan v Arzi TT Manukau 4024444, 4 November 2016 at [34].

95 See for example Lenny $v$ Winiata TT Rotorua 15/01001/RO, 29 June 2015; and Rentables Ltd v Henare Palmerston North TT 4012938, 28 April 2016.

96 This is established by keyword searching for "Osaki", and no hits being returned until after the High Court decision. For examples of orders on careless damage, see Khan $v$ Morrison TT Palmerston North 13/01931/PM, 7 February 2014; Seddon v Peacock TT Tauranga 13/01657/TG, 11 February 2014; Wilson v 
It is not clear why the District Court decision had no effect on the Tribunal's practice, but it may be that it was simply not brought to the Tribunal's attention. It is probable that tenants did not know of the decision, and parties to tenancy disputes are generally not represented by lawyers. ${ }^{97}$ If "merits and justice" discretion in s 85 was being used to not apply the District Court's decision one would expect reasoning to that effect in the order. Instead, Holler $v$ Osaki was not mentioned, which suggests that adjudicators simply were not aware of it.

\section{B Effect of the High Court Decision before the 2014 Practice Direction}

\section{Full exoneration}

In contrast, there clearly was an awareness of the High Court decision after it was handed down on 20 August 2014, for there was a definite response from the Tenancy Tribunal. A number of adjudicators applied Holler $v$ Osaki's reasoning to all kinds of careless tenant damage - whether minor or catastrophic - by either exonerating the tenant from liability or refusing to make any order before the landlord had provided information about its insurance arrangements. ${ }^{98}$ Adjudicators often took some care to explain why they could no longer award compensation for careless damage caused by

Gould TT Blenheim 14/00019/BM, 13 March 2014; Coates $v$ Wright TT Tauranga 13/01820/TG, 12 March 2014; Housing New Zealand Corp v Nikora TT Auckland 13/02198/HE, 13 March 2014; Hendriks v Iron Bridge Property Management (Auck) Ltd TT Tauranga 14/00231/TA, 18 March 2014; Thorpe v Brown TT North Shore 14/00351/TA, 26 March 2014; and Goode Leith Realty Ltd $v$ Lee TT Whangarei 14/00631/WR, 13 June 2014.

97 See Residential Tenancies Act, s 93.

98 Powell v O'Hanlon TT North Shore 14/01074/TA, 23 September 2014; Berriman v Singh TT Manukau 14/05228/MK, 22 September 2014; Butcher v Horncastle Property Management Ltd TT North Shore 14/01080/TA, 23 September 2014; Sloss v McKee TT Christchurch 14/02472/CH, 9 October 2014; Christchurch City Council v Stevenson TT Christchurch 14/02490/CH, 23 October 2014; Ha v Healey TT Christchurch 14/02474/CH, 30 October 2014; Clarke v Wilson TT Auckland 14/01786/HE, 3 November 2014; Housing New Zealand Corp v Coker TT Porirua 14/00907/PO, 5 November 2014; Charta Management Ltd v Murray TT Auckland 14/01753/HE, 7 November 2014; Sheppard v Mosen TT Auckland 14/01742/HE, 7 November 2014; The Wong Family Trust $v$ Vahaakoto TT Manukau 14/06690/MK, 10 November 2014; Otaki Rentables Ltd Agent for Rikki Jones v Chapman TT Porirua 14/00933/PO, 12 November 2014; Guv Leary TT Christchurch 14/02595/CH, 12 November 2014; Preet \& Co Rentals Ltd v Iripa TT Manukau 14/06669/MK, 12 November 2014; Steven v Tonga TT Tauranga 14/01374/TG, 14 November 2014; $K$ \& V Properties Ltd v Cowley TT Auckland 14/02064/HE, 18 November 2014; James \& Kushla Property Co Ltd $v$ Herewini TT Rotorua 14/01358/RO, 19 November 2014; Esquilant v Mana Property Management Ltd TT Dunedin 14/00833/DN, 25 November 2014; Brogden v Skidmore TT Christchurch 14/02731/CH, 25 November 2014; Wongeoon Vast Ltd v Vaitohi TT Christchurch 14/02719/CH, 28 November 2014; Court v Star TT North Shore 14/01399/TA, 4 December 2014; Moore v Rowe TT Wellington 14/01384/WN, 5 December 2014; Pride Property Management Ltd Agent for Rex Beech v Hetaraka TT Invercargill 14/00648/IN, 8 December 2014; Barbarich v BJN Properties Ltd TT Gisborne 14/00368/GS, 11 December 2014; and Mitchell v Manu TT Christchurch 14/02634/CH, 12 December 2014. 
the tenant, by setting out the PLA exoneration provisions and by explaining the effect of the High Court's decision. For example, one adjudicator stated that under Holler v Osaki: ${ }^{99}$

... the Tribunal has no option but to find that where landlords are insured against the loss claimed, and even if the loss was caused by the tenant's negligence, the landlord can no longer recover the loss directly from the tenants. Effectively, the tenants are entitled to the benefit of the landlord's insurance.

In a later decision, the same adjudicator explained that the law relating to the tenant's liability for careless or intentional damage: ${ }^{100}$

... has now been modified by the recent decision of Holler $v$ Osaki [2014] NZHC 1977. Here the High Court held that in exercising its jurisdiction the Tribunal must look to Part 4 of the Property Law Act 2007 as a source of the general principles of law relating to a matter provided for in that Part. In other words residential tenants facing claims under the Residential Tenancies Act 1986 are now entitled to claim the same immunity expressly given to commercial tenants under the Property Law Act. ... Therefore, in most instances when considering whether the tenants can be held liable for repair costs, the Tribunal now requires evidence from the landlord on whether or not the landlord is able to benefit from an insurance claim for this damage. The [T]ribunal must also consider whether the loss claimed was caused by the negligent or intentional actions of the tenant or someone entitled to be on the premises. The distinction is new to the Tribunal.

In another order, the adjudicator explained the application of Holler v Osaki to the landlord claimant, Housing New Zealand:101

General comment on damages claims: I explained to Ms Smith appearing for Housing New Zealand at the hearing that a recent High Court decision, Holler \& Rouse v Osaki CIV 2013-404-4548, has raised an issue relevant to damages claims.

$\cdots$

What this means is that if the premises are damaged by fire, flood, etc, or any other peril against the risk of which the landlord is insured (or has agreed to insure) then the landlord cannot require the tenant to meet the cost of making good the damage, indemnify the landlord, or pay compensation in respect of the damage, even though the damage is caused or contributed to by the negligence of the tenant or anyone associated with it.

99 Butcher v Horncastle Property Management Ltd, above n 98 at [9]. The same reasoning is found in Powell $v$ O'Hanlon, above n 98.

100 Tuthill v Croon TT Auckland 14/01937/HE, 18 November 2014 at [3] and [5].

101 Housing New Zealand Corp v Coker, above n 98, at [10]-[12]. See also The Wong Family Trust v Vahaakoto, above n 98; Otaki Rentables Ltd Agent for Rikki Jones v Chapman, above n 98; and Steven v Tonga, above $\mathrm{n}$ 98 . 
The vast majority of Tribunal orders placed on the database that mention the decision in Holler $v$ Osaki between the date of the High Court decision and the date of the Practice Direction apply the case as a precedent requiring them to exonerate the tenants of liability, where the PLA provisions would have exonerated a commercial tenant. In addition, some adjudicators applied reasoning congruent with Holler $v$ Osaki without citing it. ${ }^{102}$ Some orders concerned fire damage, and as the issue was not discussed, it is not clear whether a wider or narrower view of Holler v Osaki was being taken. ${ }^{103}$

\section{Partial exoneration}

However, the application of Holler v Osaki in Tribunal orders was not uniform. That adjudicators were uneasy with the change in Tribunal practice forced by the High Court's decision is reflected in the way that some adjudicators found that Holler $v$ Osaki did not apply to exonerate the damage caused by the tenant. This goes beyond situations where adjudicators simply found that the landlord did not have insurance cover for damage caused by the tenant, for this effectively applies the High Court's decision. ${ }^{104}$ Beyond this, adjudicators found it possible to distinguish Holler v Osaki: one adjudicator used the discretion given by ss 142 and 85 to make the tenant liable for their careless damage to the landlord's property despite the landlord being insured. ${ }^{105}$ This was based on a distinction in the type of event and damage: 106

It is debatable whether that High Court decision intended that this general principle is to apply regardless of the degree of damage or to damage other than fire damage.

$\ldots$

The situation discussed in the High Court decision differs substantially from the damages claims in these applications. The damage was a significant one-off event with a very dramatic and expensive consequence. The facts are too different to those in the current applications for me to ignore Section 142(1) that says nothing in the Property Law Act 2007 shall apply. Therefore I find that the High Court decision does not apply to the damage claims in these applications.

102 RER Property Management v Morgan TT Manukau 14/05412/MK, 12 September 2014; and Alexey Trust Ltd $v$ Chapman TT Auckland 14/01429/HE, 16 September 2014.

103 Optimize Realty Ltd v Ward TT 14/01039/WR, 26 September 2014; and Barbarich v BJN Properties Ltd, above n 98

104 Charta Management Ltd v Murray, above n 98; and Gu v Leary, above n 98.

105 Robinson v Telfer TT Auckland 14/01765/AK, 5 December 2014.

106 At 12 . 
This reasoning was applied by this adjudicator in other orders. ${ }^{107}$ Interestingly, this reading of Holler v Osaki as limited to fire damage or dramatic, one-off, expensive events - which we may term "catastrophic damage" - was later to be taken up by the Principal Tenancy Adjudicator's Practice Direction, discussed below.

Another approach was to say that the application of principles of law found in pt 4 of the PLA was discretionary, and should not be applied where this was contrary to the merits of the dispute. Thus, an adjudicator stated that s 142(2) merely provides a discretion to adjudicators, which allowed the adjudicator to remedy a claim for the excess paid by a landlord to their insurer: ${ }^{108}$

... s 142(2) provides that the Tribunal, "in exercising its jurisdiction in accordance with s 85" of the RTA,

"may" look at those sections "as a source of ... general principles of law" relating to leases covered by the

PLA. Therefore reference to ss 268 to 270 PLA is discretionary.

The adjudicator also thought that it was necessary for policy reasons to make a distinction between the exoneration of liability (a) for the damage to the landlord's property and (b) to compensate the landlord's loss in having to pay their insurance excess: ${ }^{109}$

$\ldots$ if the decision in Osaki were to be extended to the excess, or to cases where the amount claimed is below the level of the excess, in a large number of cases the landlord would not be able to bring a claim against the tenant. That is because most rental properties are likely to be insured, and careless damage is likely to be covered by most insurance policies. The practical effect would [be] to create a significantly different outcome for a landlord, depending on whether damage was careless or intentional. It would also create the perverse effect of the landlord being disadvantaged by having insurance in cases of minor careless damage.

Fulfilling the adjudicative role under s 85 , the adjudicator declined to relieve the tenant from liability for compensating the landlord's loss relating to their excess.

\section{Continuing tenant liability without mentioning Holler v Osaki}

In addition to these decisions that "distinguished" Holler $v$ Osaki or used s 85 to make the tenant liable, other cases simply continued the Tribunal's previous practice with respect to liability for careless damage. This occurred in almost as many orders as the application of the exoneration provisions. Indeed, in these orders, Holler v Osaki was not referred to at all, and so there was no analysis of whether the tenant should be exonerated from liability - or of the subsidiary questions of

107 Robinson v Telfer, above n 105. See also Ballantine v Sproule TT Tauranga 14/01454/TG, 10 December 2014; and $A \&$ \& Bomes $v$ Garnel TT 14/01421/TG, 10 December 2014. This reasoning was also applied later in Van Vliet $v$ Russell Hardie Ltd TT Rotorua 15/01672/RO, 28 October 2015.

108 Purple Phoenix Ltd v Harrison TT Tauranga 14/01329/TG, 26 November 2014 at [5(b)]. See also Ballantine v Sproule, above n 107; and A \& B Homes Ltd v Garnel, above n 107.

109 Purple Phoenix Ltd v Harrison, above n 108, at [5(c)]. 
whether the tenant's actions were careless rather than intentional or whether the landlord had a relevant insurance policy. ${ }^{110}$ Because it is simply not mentioned, it is not clear whether adjudicators in these cases were unaware of Holler $v$ Osaki, or did not address it because it was not mentioned by the tenant, or thought that the decision did not apply to situations where the damage was not caused by catastrophic events.

What is clear is that there were three main responses to the High Court's decision in Holler $v$ Osaki. Many orders applied all of the PLA exoneration provisions to all kinds of careless damage. A similar number of orders did not apply the exoneration provisions to careless damage claims, but without mentioning Holler v Osaki. And a small minority of orders distinguished the reasoning in Holler $v$ Osaki from the damages claim they were dealing with. This shows that there was a clear split in the Tribunal, with different legal rules being applied by adjudicators to the same legal question. This split does not necessarily reflect any problem for the doctrine of precedent, for it may be that those who did not mention Holler $v$ Osaki were unaware of the decision or were among those who distinguished it. However, it still demonstrates a concerning inconsistency in Tribunal practice.

\section{Principal Tenancy Adjudicator's 2014 Practice Direction}

Perhaps responding to this inconsistency in the Tribunal's application of the law, on 12 December 2014, three and a half months after the High Court's decision in Holler v Osaki, the Principal Tenancy Adjudicator issued a Practice Direction in response to the decision, pursuant to her power under s 115 of the RTA. ${ }^{111}$

The Practice Direction stated that the High Court's decision meant that where a property subject to a residential tenancy suffers damage due to a fire caused by the carelessness of a tenant or his or her agent, the tenant is entitled to claim immunity against an application to the Tenancy Tribunal by

110 City Apartments Ltd v Young TT Auckland 14/02335/AK, 22 August 2014; McLeod v Ryland TT Christchurch 14/02094/CH, 2 September 2014; Pert v Barton TT Auckland 14/01284/HE, 2 September 2014; Dolgova v Gandhimani TT Auckland 14/02475/AK, 10 September 2014; SJC Properties Ltd v Hunapo TT Hamilton 14/01322/HN, 19 September 2014; Ingram v Singh TT Hamilton 14/01923/HN, 20 September 2014; Kelly v Budomo TT Auckland 14/02633/AK, 30 September 2014; Inspire Property Management Ltd $v$ Conroy TT Manukau 14/06225/MK, 8 October 2014; Kram v Porter-Pomare TT Auckland 14/03017/AK, 8 October 2014; Thielke v Gibbon TT Auckland 14/02514/AK, 9 October 2014; Ray White Kerikeri v Dwight TT Whangeri 14/00934/WR, 21 October 2014; Sharma v Orakawa Holdings Ltd TT Auckland 14/02854/AK, 22 October 2014; Te Paea v Allen Realty Ltd TT Manukau 14/06428/MK, 28 October 2014; Zhao v Tana TT Manukau 14/06332/MK, 29 October 2014; The Packingshed Cafe Ltd v Rowe TT Christchurch 14/01758/CH, 29 October 2014; Morriss v Morgan TT Manukau 14/06468/MK, 7 November 2014; Creak $v$ Wright TT Auckland 14/02447/AK, 12 November 2014; Lewis v McEvoy TT Manukau 14/06647/MK, 19 November 2014; Situ v Feiloakitau TT Auckland 14/03306/AK, 27 November 2014; and Waitakere Real Estate Ltd v Tangiiau TT Auckland 14/00664/HE, 4 December 2014.

111 Principal Tenancy Adjudicator, above n 87. 
the landlord for damages or compensation. ${ }^{112}$ However, it limited the application of the exoneration provisions to only the "catastrophic event[s] found in s 268(1)(a) of the PLA07". ${ }^{113}$ Outside of those catastrophic events, a tenant is still liable for carelessly damaging the property in breach of ss 40 or 41 of the RTA, and the Tribunal "will apply its current jurisprudence". ${ }^{114}$ The Direction also stated that even if the tenant is exonerated from liability in regards to the catastrophic event, the landlord may make a claim for the excess. ${ }^{115}$ Thus the Practice Direction identified a more limited legal rule than in the District and High Courts' decisions: it distinguished between careless damage caused by fire, and damage caused otherwise by tenants' carelessness.

Although the Direction brought the High Court decision to adjudicators' attention and stated a reasonable rule for tenant liability for careless damage that would cause the minimum of disruption to the Tribunal's prior practice, the legal basis for this distinction was not explained, and it is not obvious. Such a distinction between catastrophic events and non-catastrophic damage is not found in the exoneration provisions themselves. Nor is it found in the High Court summary judgment decision, ${ }^{116}$ or in the District Court decision. ${ }^{117}$ It is also not evident in the High Court's reasoning, which did not turn on the specific cause of damage, whether fire or catastrophic events generally. ${ }^{118}$ Keane J held that "tenants holding residential tenancies facing claims under the RTA are entitled to claim the immunity that the PLA accords to lessees generally". ${ }^{119}$ His view was that the exoneration provisions should apply to residential tenancies under s 142 of the RTA. ${ }^{120}$ The Judge's legal conclusion is stated in general terms without making the distinctions found in the Practice Direction. $^{121}$

Given that the question of the type of damage does not seem material to Keane J's reasoning and decision, a plausible interpretation of the effect of the District and High Court's decisions is that the exoneration provisions as a whole were to be applied to all questions of liability for damage to which they would apply if they were not excluded from applying to residential tenancies. This interpretation

112 At [1].

113 At [3].

114 At [4].

115 At [2].

116 Holler v Osaki (summary judgment), above n 26.

117 At [55]-[58], speaking generally of the applicability of ss 268-269 of the Property Law Act.

118 Holler v Osaki (HC), above n 2, [29]-[30] and [48].

119 At [49].

120 At [29]-[30] and [48].

121 At [29]-[30]. 
is at least arguable, as the Tenancy Tribunal orders that subsequently applied such an interpretation confirm.

In addition, the more general view of the law found in the District and High Court decisions is also reflected by the questions stated by the appellants in the appeal application, which did not make such a distinction. ${ }^{122}$ This question was stated by the High Court on 21 October 2014, two months after the substantive decision but before the Practice Direction was issued. The relevant question was "[w]hether residential tenants are immune from a claim by the landlord where the rental property suffers loss or damage caused intentionally or carelessly by the tenant or the tenant's guests?" 123 Keane $\mathrm{J}$ accepted this statement of the issue, but added this observation: ${ }^{124}$

\footnotetext{
The questions of law to which my decision gives rise might conceivably be expressed more narrowly than the appellants propose. In my decision, for instance, the questions I identified were these, "In imposing liability on tenants for fire damage, does the RTA incorporate by reference ss 268 and 269 of the PLA, insofar as they exonerate tenants from liability? Or does it deny them any operative effect?" But because my own questions are worthy of a second appeal and necessarily arise on the questions proposed, any refinement of those proposed is to be resolved on the appeal itself.
}

The Court of Appeal characterised the question in its wider ambit, saying that the case turned on whether ss 268-269 of the PLA apply to residential tenancies. ${ }^{125}$

However, there is one key point in the High Court's decision where such a distinction is suggested: where the Judge states the issue to be decided in the case: ${ }^{126}$

The issue on this appeal involves, therefore, the extent to which the PLA, Part 4 of which governs leases generally, applies to residential tenancies, a form of tenure created and governed by the RTA. More particularly, as it relates to Mr Osaki, it involves two questions. In imposing liability on tenants for fire damage, does the RTA incorporate by reference ss 268 and 269 of the PLA, insofar as they exonerate tenants from liability? Or does it deny them any operative effect?

Although the first statement of the issue indicates the general question that determined the result, the second issue statement seems to limit the question that is being determined in the case to tenant liability for fire damage. This might be a reason for a limited interpretation of the binding reasons from the High Court decision. And as noted above, this was perhaps the only way that the Principal

122 Holler v Osaki (CA), above n 3, Statement of Questions.

123 The reference to intentional must be incorrect, as tenants are never exonerated from liability for intentional damage under the Property Law Act provisions.

124 Holler v Osaki [2014] NZHC 2470 at [4].

125 At [1].

126 Holler v Osaki $(H C)$, above n 2, at [7]. 
Tenancy Adjudicator could interpret the High Court's decision as not meaning that most of the Tribunal's orders in relation to careless damage since 2007 incorrectly failed to exonerate tenants and that the Tribunal must therefore completely change its practice of holding tenants liable for careless damage. This pragmatic concern does not mean the Practice Direction was the best interpretation of the High Court's decision, but it is an obvious reason for taking the narrower approach to exonerating liability.

\section{Effect of the 2014 Practice Direction}

Examining orders relating to careless damage after it was made reveals that despite the Practice Direction, the split observed in Tribunal practice after the High Court decision continued through 2015 and 2016, until the Court of Appeal's decision. There was, however, a change in the numbers of adjudicators taking each position, with many more orders giving effect to the Practice Direction than the wider interpretation of the High Court's decision.

\section{Partial exoneration - applying the Practice Direction}

The Practice Direction had an immediate effect, leading adjudicators to apply the Practice Direction's interpretation of the law and to distinguish between careless damage generally and catastrophic damage in applying the exoneration provisions. Just three days later, on 15 December 2014, an adjudicator observed: ${ }^{127}$

Damages claims generally: I mentioned at the end of the hearing that there has been a High Court decision of Holler \& Rouse $v$ Osaki which may have a bearing on this case. However, a practice direction issued by the Principal Tenancy Adjudicator on 12 December 2014 has clarified the Tribunal's position as to the application of the High Court decision. In this case, the landlords' claims for careless damage caused by the tenants is within sections 40 and 41 of the Act, and therefore the Tribunal will apply its current jurisprudence.

In another early application of the Practice Direction, the adjudicator stated that: ${ }^{128}$

... my preliminary view of the effect of the High Court's decision [in Holler v Osaki] was that this decision (and Ms Quinton's insurance cover) could well operate to provide Ms Hampton with an immunity on account of the provisions of sections 268-269 of the Property Law Act 2007. However, after giving the matter some further consideration and after taking into account the recent Practice Direction issued by the Principal Tenancy Adjudicator on the issue, I find that the Osaki decision is distinguishable on the facts of the present dispute ... For this reason no immunity under sections 268-269 arises ...

The reason it is distinguishable is not given.

127 Brophy v Taylor TT Wellington 14/01461/WN, 15 December 2014 at [14] (citations omitted). See also Brickland v Gage TT Rotorua 14/01920/RO, 15 January 2015.

128 Hampton v Quinton TT Auckland 14/01895/AK, 30 January 2015 at [13]. 
In addition, other adjudicators distinguished the High Court decision in Holler $v$ Osaki by reference to the nature of the damage without mentioning the Practice Direction. ${ }^{129}$ Where the damage was catastrophic, some adjudicators applied the exoneration provisions, but usually with reasoning that seemed to limit their application to catastrophic events; ${ }^{130}$ other cases were more ambiguous as to whether they would limit the application to such catastrophic events. ${ }^{131}$

In other orders, the adjudicators noted that Holler v Osaki was under appeal. ${ }^{132}$ This led one adjudicator to adjourn the case: 133

The urgency point is tied to the uncertain legal position as a result of the decision of the High Court in

Holler \& Rouse v Osaki. The High Court's decision is presently under appeal to the Court of Appeal, and

it is preferable for the Tribunal to await the decision of the Court of Appeal before making its own decision

in the present case.

As this case was about damage caused by a fire, it seems that the adjudicator may have been cognisant that the Court of Appeal might have held that the exoneration provisions did not apply to residential tenancies at all, which would have meant that the tenants were liable for the damage they caused.

\section{Continuing tenant liability?}

Just as before the Practice Direction, a large number of decisions simply awarded damages for non-catastrophic careless damage to property without referring to Holler $v$ Osaki or the exoneration provisions at all. ${ }^{134}$ However it is likely that these decisions were also applying the Practice Direction

129 Yuan v Maharaj TT Auckland 14/03238/AK, 2 February 2015; Property Brokers Ltd - Manawatu \& Wanganui v Roy TT Palmerston North 15/00567/PM, 5 June 2015; Croft v Gill TT Palmerston North 15/00385/PM, 6 July 2015; McLean v Williams Dunedin TT 15/00419/DN, 14 July 2015; Liddell v Kaa TT Hamilton 15/01232/HN, 18 August 2015; O'Connor v Kerr TT Dunedin 15/00511/DN, 22 September 2015; and Donaldson v Karana TT Pukekohe 15/07001/MK, 3 March 2016.

130 Morriss $v$ Sonntag TT Dunedin 14/00924/DN, 10 February 2015; Panapa v Morrison TT Hamilton 14/02024/HN, 17 February 2015; Housing New Zealand v Te Whau TT Rotorua 14/02360/RO, 20 May 2015; and Harris v Fergusson TT Christchurch 14/02969/CH, 4 May 2015.

131 Severinsen v Kava TT Hastings 14/01267/NA, 15 December 2014; Lenny v Winiata, above n 95; and Ruiz v Lisa Petch Family Trust TT Tauranga 4002012, 3 February 2016.

132 Chalmers $v$ Webb TT Christchurch 14/02618/CH, 23 December 2014; and Low v Champagne Homes Ltd TT Christchurch 14/02769/CH, 23 January 2015.

133 Housing New Zealand Corp v Foliaki TT Wellington 14/01367/WN, 12 February 2015 at 2.

134 Pederson v McDowell TT Auckland 14/03706/AK, 8 January 2015; Scurfield v Staunton TT Manukau 14/07796/MK, 16 January 2015; Stevenson v Law TT New Plymouth 14/00602/NU, 16 January 2015; Harvic Residential Property Management Ltd v Pearce TT Wellington 14/01589/WN, 16 January 2015; Wellington City Council - City Housing v Perez. TT Wellington 14/01598/WN, 16 January 2015; Lloyd v Wait TT Christchurch 14/03004/CH, 13 February 2015; Kumar v Taotua TT Auckland 15/00310/MK, 16 February 2015; Collins v Scott TT Christchurch 15/00033/CH, 26 February 2015; Dodunski v Nelson TT Hastings 15/00047/NA, 11 November 2015; Quinovic Property Management Ltd v Dijkstra TT Christchurch 
without referring to it or Holler $v$ Osaki, because the previous practice of the Tribunal was applicable to non-catastrophic damage.

\section{Full exoneration - not applying the Practice Direction}

Although the bulk of orders seemed to apply the Practice Direction, ${ }^{135}$ even if implicitly, there were still a small number of orders that applied the wider view of the High Court decision - that the exoneration provisions apply to all carelessly caused damage, not just catastrophic damage. These orders, made contrary to the Practice Direction, demonstrate some of the uncertainty about the binding effect of such Directions. For they may have reflected the adjudicators' view that the wider interpretation of the High Court's decision was correct, and that they should therefore apply the law rather than the Practice Direction. It seems unlikely that the adjudicators would be unaware of the Direction.

Therefore, the question of whether practice directions are binding is another uncertainty in the RTA. Such practice directions are issued for "the purpose of ensuring that the application and administration of this Act is consistent throughout New Zealand". ${ }^{136}$ They provide for the "guidance of other Tenancy Adjudicators, officers of the Tribunal, and parties before the Tribunal". ${ }^{137}$ Professor Grinlinton's text cites a District Court decision stating that such directions are not binding. ${ }^{138}$

On one hand, this seems contrary to the intention of s 115 of the RTA in the present context: on such a crucial and binary question of the applicability of the exoneration provisions, adjudicators should apply the same legal test. On the other hand, it is not clear that s 115 provides the Principal Tenancy Adjudicator the power to give binding interpretations of the RTA, and if it does not then

15/00476/CH, 17 March 2015; Hill v Bedford TT Blenheim 15/00002/BM, 18 March 2015; Goode Leith Realty Ltd T/A Ray White - Allens v Do TT Whangarei 15/00264/WR, 30 April 2015; Perry v Sinclair TT Tauranga 15/00314/TG, 22 April 2015; Crockers Property Management Ltd v Karanga TT Manakau 15/01082/MK, 25 May 2015; For Homes (NZ) Ltd v Trow TT Palmerston North 15/00685/PM, 4 June 2015; Firth $v$ Jager TT North Shore 15/00798/TA, 25 August 2015; Pinchin v Hassan TT Christchurch 15/00750/CH, 26 August 2015; Forsyth v Ferrari TT Christchurch 15/01743/CH, 14 September 2015; Kamota $v$ MacFarlane TT 15/01735/CH, 17 September 2015; Murphy v Larsen TT Tauranga 15/01079/TG, 23 September 2015; Peacock v PPM Rentals TT Palmerston North 15/01193/PM, 8 October 2015; Sparks v Taylor TT Greymouth 15/00063/GM, 22 October 2015; Horncastle Property Management Ltd $v$ Hall TT Christchurch 15/02254/CH, 3 November 2015; Rennell v Lill TT Christchurch 15/02229/CH, 1 December 2015; and Moate v Reid TT Invercargill 15/00534/IN, 22 February 2016.

135 Payne v Oliver TT Tauranga 14/01371/TG, 14 January 2015; Iron Bridge Property Management Ltd v Gallacher TT Manukau 14/07483/MK, 3 February 2015; Thompson v Te Aro Tenancies Ltd TT Wellington 14/01671/WN, 10 March 2015; Van Vliet v Russell Hardie Ltd TT Rotorua 15/01672/RO, 28 October 2015; and Champagne Homes Ltd v Jose TT Christchurch 4015765, 21 April 2016.

136 Residential Tenancies Act, s 115.

137 Section 115 .

138 Grinlinton, above n 20, at 266, citing Morton v Murdoch DC Dunedin TT765/96, 18 November 1996. 
adjudicators should give effect to their understanding of the law in cases where it conflicts with a Practice Direction. The two decisions cited above applying the Practice Direction's partial exoneration approach reveal some uncertainty as to whether the Practice Direction is binding. The first adjudicator presenting it as stating how the Tribunal should apply Holler v Osaki, and the second adjudicator saying that the Practice Direction was merely "taken into account".

This is a further uncertainty in the RTA that should be remedied. It may be that the ability for a Tribunal to state a case for the opinion of the High Court under s 103 of the RTA should be used by the Principal Tenancy Adjudicator in cases where a difficult question of law has arisen, which would allow a binding precedent to be created.

\section{E The Effect of the Court of Appeal's Decision}

As we have seen, the Court of Appeal did clarify the legal position, in a decision given on 15 April 2016. Its interpretation of the law, which made no distinction between types of damage and simply stated that the exoneration provisions were to apply to residential tenancies in full, was applied by an adjudicator on 24 April 2016. ${ }^{139}$ It was applied consistently after this, ${ }^{140}$ although there was at least one early exception. ${ }^{141}$ Tribunal adjudicators sometimes explicitly referred to their being bound to apply the Court of Appeal's decision. ${ }^{142}$

On 26 July 2016, the Principal Tenancy Adjudicator published a Practice Note giving effect to the Court's decision. ${ }^{143}$ It recognised that the PLA exoneration provisions were accordingly to be applied in full and gave detailed guidance on how to apply the Court of Appeal's decision, including a statement that excess could not be claimed. This provided landlords and tenants with confirmation of

139 Brazier Property Investments Ltd v Penitani TT Christchurch 4015815, 21 April 2016.

140 Deane v Te Rore TT Blenheim 4018863, 2 May 2016; Reeve v Blomquist TT Christchurch 4015492, 3 May 2016; Kim v Peterson TT North Shore 4011310, 5 May 2016; Downey v Kidd TT Nelson 4022208, 11 May 2016; Polglase v Clemments TT Nelson 4019799, 12 May 2016; Hamilton Family Trust v Hockey TT Nelson 4017185, 12 May 2016; Bayleys Property Services Ltd v Pinkerton TT Waitakere 4050011, 9 January 2017; and Taylor Property Management v Hopoate TT Manakau 4055451, 31 January 2017. There are almost 700 references to the case between May 2016 and March 2017. In Candy v van der Westhuizen TT Manukau 4021186, 19 October 2016 the adjudicator refers only to the High Court decision.

141 O'Reilly-Nugent v Stobie-Ross TT Hastings 4011979, 28 April 2016.

142 Strickland v Sarkar TT Huntly 4050731, 27 January 2017; Dryland v McTainsh TT Hamilton 4055936, 19 December 2016; Gralin Property Management Ltd v Thomas TT Auckland 4048550, 16 December 2016; and Elkington v Mayston TT Hamilton 4047025, 12 December 2016.

143 Tenancy Tribunal Practice Note 2016/1: Tenant Liability for Damages (2016). 
the Court of Appeal's decision and explained its implications. Some Tribunal orders referred solely to the Practice Note. ${ }^{144}$ The legal position was also widely reported in the media. ${ }^{145}$

There have been decisions that limit Holler v Osaki's impact. For example, s 42(6) of the RTA provides for tenant liability for remedying damage caused by removing fixtures, and an adjudicator held that this specific provision for remedy excluded the operation of the PLA's exoneration provisions. ${ }^{146}$ Where damage was caused by pets, this was regarded as intentional if it was the inevitable consequence of having the pet inside. ${ }^{147}$ Pet damage is also sometimes an exclusion under the landlord's insurance policy, which would prevent the exoneration provisions from applying. ${ }^{148}$ Despite this, in one case where damage by a landlord's own pet was insured for, but not damage by their tenants' pets, the adjudicator characterised this as inadequate cover rather than lack of insurance. ${ }^{149}$ Tenants are still liable for not leaving the property reasonably clean. Other cases have noted that the landlord's insurance policy might not protect against the particular peril that caused the damage. ${ }^{150}$ However, claims that the landlord is not insured because they have to pay an excess have not been allowed. ${ }^{151}$

The effect of the Court of Appeal's decision was also the subject of a letter sent from the Principal Tenancy Adjudicator to the Minister of Building and Housing on 23 September 2016. ${ }^{152}$ It provides a strong argument in favour of a legislative fix for the legal situation resulting from the Court of Appeal's decision. She notes that, although there might be good reasons for exonerating tenant liability for major damage as found in the Holler $v$ Osaki facts, no distinction on this basis was drawn by the Court of Appeal. This means that for the "kind of damage that is the core business of the Tribunal on a daily basis throughout the country" the Tribunal "can no longer award damages against a tenant for

144 Shrivastava v Pickled Parrot Property Management Ltd TT Wellington 4051626, 23 November 2016.

145 See for example "Rental property damage: Landlords liable - court rules" The New Zealand Herald (online ed, Auckland, 21 April 2016).

146 Eves Realty Ltd v Bentley TT Tauranga 4050136, 4 January 2017.

147 Lewis v Dawson TT Christchurch 4027937, 21 July 2016; Quinovic Property Management t/a Whitby Property Management Ltd v Walton TT Porirua 4049667, 28 November 2016; Burtshaw Investments Ltd v Buck TT Palmerston North 4051915, 10 January 2017; and Gibbs v McAtear TT Queenstown 4056345, 26 January 2017. See also Tekoa Trust v Stewart [2016] NZDC 25578; and Thomas Gibbons "Residential Tenancies after Holler v Osaki" (2017) 17 Conveyancing Bulletin 401.

148 Morris v Woodhouse TT Lower Hutt 4037038, 11 August 2016.

149 Clelland v Bester TT Porirua 4020710, 29 July 2016.

150 Brazier Property Investments Ltd v Penitani [2017] NZDC 1291.

151 Powell Holdings Ltd v Steele TT Lower Hutt 4008066, 1 June 2016; and Initial Realty Ltd v Davis TT Christchurch 4035467, 12 September 2016.

152 Letter from Melissa Poole to Nick Smith, above n 6. 
careless damage if the landlord holds insurance for the risk of that particular kind of damage". This is understandably presented as a major problem for the Tribunal, hampering its day-to-day functioning due to the necessity of addressing the landlord's insurance cover in each application relating to careless damage, and resulting in landlords not being awarded compensation for damage that the RTA "clearly envisaged the tenant bearing responsibility for".

The Principal Tenancy Adjudicator's letter also notes a concern for the reputation of the Tribunal due to landlord anger about the decision, and their view that tenant liability for minor damage should not be exonerated - as well as anecdotal evidence of landlords leaving the industry. Finally, the Principal Adjudicator recommends an amendment to s 142 in order to clarify the law and prevent the kind of confusion that has resulted from the decision, stating that "[t]he Tribunal now operates daily with an unwieldy amalgam of legislation and binding judicial precedent that has effectively fettered a core principle" of the RTA.

The Government has responded to these suggestions - and pressure from landlords - by proposing an amendment to the RTA, contained in the Residential Tenancies Amendment Bill (No 2). ${ }^{153}$ The Bill would essentially limit a tenant's liability for damage caused by a careless act or omission to four weeks' rent or the insurance excess if the property is insured by the landlord against the damage. ${ }^{154}$ This was essentially the proposal that was rejected in $2008,{ }^{155}$ but in light of the reasons of policy and principle that were canvassed in the Law Commission's reports and in the Holler v Osaki decisions, it seems a marked improvement over both the previous and present legal situations. The Bill is in Select Committee, which is due to report back on 29 March 2018.

\section{CONCLUSION}

The law relating to residential tenancies should be straightforward enough that people can apply it to their situation or prospective tenancy arrangements without confusion or the need to consult a lawyer. The saga of the exoneration demonstrates further examples of the lack of clarity that currently exists in the RTA, and the problems this causes for achieving consistent application of the law in the Tribunal. This article demonstrates that, for a time, completely different legal rules were being applied to substantially identical situations in the Tenancy Tribunal, depending on which adjudicator was deciding the dispute. The proposed legislative fix for the Holler $v$ Osaki decision is therefore welcome, and it seems to balance the substantive justice of the policy question of tenant exoneration in a reasonable way. The proposal to do away with s 142(2) is also sensible, but further consideration should be given to clarifying the adjudicative direction found in $\mathrm{s} 85$.

153 Residential Tenancies Amendment Bill (No 2) 2017 (258-1).

154 Clause 7 inserting ss 49A-49E into the Residential Tenancies Act.

155 Residential Tenancies Amendment Bill (No 2) 2008 (217-1), cl 26. See Holler v Osaki (CA), above n 3, at [55]. 
Although there have been some other good developments in the law of residential tenancies - for example, the requirements for smoke alarms and insulation, ${ }^{156}$ and the tightening of rules around retaliatory eviction ${ }^{157}$ - it is high time for the enactment of a new Residential Tenancies Act. This should occur after an appropriately comprehensive and participatory examination of the issues facing renters given the fundamental changes to the socio-economic structures of housing and social inequality that have played out over the last 20 years. ${ }^{158}$ Countries such as Scotland and Ireland have undertaken such inquiries and reforms over the last decade, ${ }^{159}$ and Victoria in Australia is currently examining possible reforms to their residential tenancies legislation. ${ }^{160}$ In addition to any further substantive changes that would flow from such an exercise, there should also be a clarification of $\mathrm{s}$ 85 of the RTA, stating clearly what kind of "merits-based" adjudicative discretion exists. Residential tenancy law is important for most New Zealanders' day-to-day lives, and it should be fit for purpose both in terms of the substantive rights and obligations it contains, and in terms of the clarity of the law.

156 Residential Tenancies Amendment Act 2016, ss 43-44, inserting ss 138A-138B into the Residential Tenancies Act.

157 Residential Tenancies Amendment Act, ss 16 and 46, making the giving of a retaliatory notice of termination an unlawful act for which exemplary damages up to $\$ 4,000$ may be awarded.

158 See further analysis in Bierre, Bennett and Howden-Chapman, above n 7; Mark Bennett "Security of Tenure for Generation Rent: Irish and Scottish Approaches" (2016) 47 VUWLR 363; Shamubeel Eaqub and Selena Eaqub Generation Rent: Rethinking New Zealand's Priorities (Bridget Williams Books, Wellington, 2015); Philippa Howden-Chapman Home Truths: Confronting New Zealand's Housing Crisis (Bridget Williams Books, Wellington, 2015); and New Zealand Productivity Commission Inquiry into Housing Affordability (2012).

159 See Bennett, above n 158.

160 See Victoria Department of Justice and Regulation "Fairer Safer Housing" Engage Victoria <https://engage.vic.gov.au>; and Victoria State Government Heading for Home: Residential Tenancies Act Review - Options Discussion Paper (2016). The initial reform proposals are set out at Victoria State Government "Making renting fair" <www.vic.gov.au>. 
